\title{
Obituary
}

\section{Ernst L Wynder MD DrSc hc (mult) Dr med hc, 1922-1999}

A man's life of any worth is a continued allegory, and very few eyes, can see the mystery of his lifeKeats, 1819

Ernst L Wynder, honorary life member of the American Association of Cancer Research, and president and founder of the American Health Foundation, passed away on July 14, 1999. His fervour towards disease prevention, his inspiration, and his networking efforts in the cancer research community will be very much missed. He surely is among those whose epitaphs will be written over and over, as it is even at his death impossible to evaluate the full impact of his life's work.

The legacy of Ernst Wynder as a disease prevention pioneer of the 20th century is a seed that will reach its full harvest only as coming generations will mature. The allegorical meanings of the knowledge and wisdom he has left us will translate into future generations with healthier lifestyles, especially better nutrition, and higher self esteem, because these individuals will know at an early age what their parents and grandparents learned only late in life and were reluctant to accept: lifestyle and environment when handled properly, can lead us to a long, healthy, and productive life, even if our genetic predisposition makes us high risk candidates for

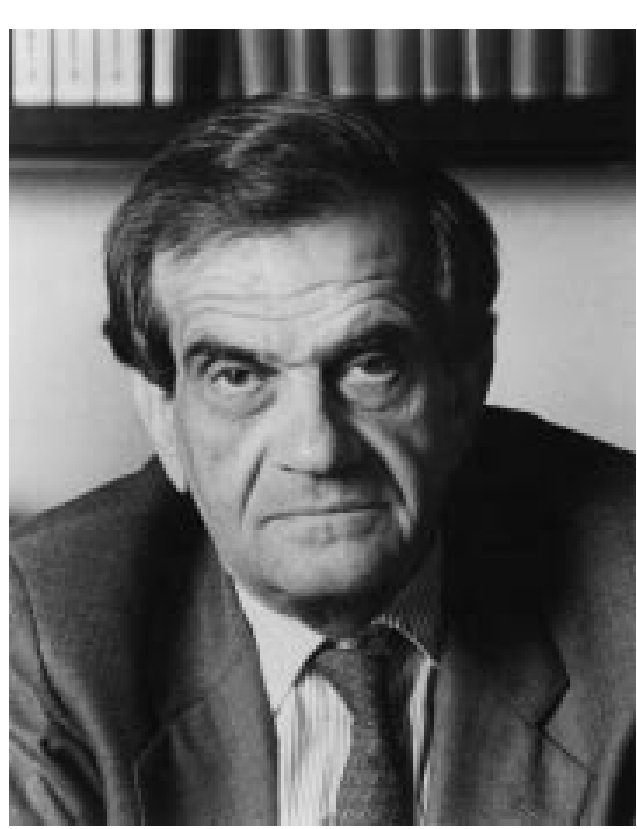

smoking. He then methodically gathered information on the deceased by questioning relatives about the occupation, lifestyle, and smoking habits of their loved ones. Thus, an epidemiologic investigation was born and it soon revealed a correlation between cigarette smoking and the frequency of lung cancer cases. In 1950, having collected 684 proven cases of lung cancer and their history, Wynder and Graham published the seminal $\mathcal{F} A M A$ paper that was later declared a landmark research article in 1985 and 1992. It preceded the first warnings from the Royal College of Physicians in England by 12 years and the first US surgeon general's report on smoking and health by 14 years.

During and after the gathering of the first epidemiologic evidence, Ernst Wynder proceeded with a logical delineation of the causality of the correlation between smoking and lung cancer, ${ }^{1}$ and, importantly, with investigations on the biology, chemistry, and biochemistry of smoking related carcinogenesis. He invited collaborators with various expertises, including Dietrich Hoffmann, a graduate of Professor Adolf Butenandt's Max Planck Institute for Biochemistry in $\mathrm{Mu}-$ cancer, heart disease, stroke, and other debilitating illness.

Born in Herford, Germany, in 1922, he arrived in the USA in 1938, earned a BA at New York University, and toward the end of the second world war found himself back in Germany as a US Army intelligence officer. Upon completion of his tour of duty, he began the study of medicine at Washington University in St Louis, Missouri, with the renowned thoracic surgeon Evarts A Graham. His keen observation of necropsy specimens led him to suspect that many of those diagnosed as having died from lung cancer must have had a history of tobacco nich, Germany, in 1957. Together, they and their colleague Stephen S Hecht can be credited with unravelling over a 40 year period many of the processes involved in tumour initiation and promotion, and also with the discovery of a tobacco alkaloid derived class of nitrosamines that cause adenoma and adenocarcinoma in the lungs of animals, and likely also in the human lung. Some of these carcinogens have become the model carcinogens against which chemopreventive efficacy of various classes of tumour inhibitors is now measured in laboratories throughout the world. 
Ernst Wynder summarised his smoking and health research in recent publications, including the American Association of Cancer Research-American Cancer Society award lecture he gave in New Orleans in $1998 .^{2}{ }^{3}$

Any evaluation of the impact that Dr Wynder's research has had on the health of the nation and, in fact, on the health of the world population, must take into account his near genius entrepreneurship. $\mathrm{He}$ was a great communicator and as such was never at a loss for words or enthusiasm when it came to motivating change. One fascinating account of his attempts to change the industry can be found in Richard Kluger's Pulitzer award winning "Ashes to ashes". ${ }^{4}$ There is of course also the record of more than 770 publications in which Dr Wynder describes worldwide cancer epidemiology as it relates to tobacco use, nutrition, and other environmental influences, as well as his laboratory studies, his prevention strategies, and health policy and philosophical issues.

His interest in global epidemiology led him to state that the world was his laboratory. The comparative studies of cancer incidence and mortality rates, especially those between the USA and Japan, prompted his laboratory investigations into the aetiology of lifestyle and nutrition related cancers which he advanced with John H Weisburger, Bandaru Reddy, Len Cohen, and David P Rose.

In terms of health policy, Ernst Wynder regarded the prevention of the major chronic illnesses, foremost tobacco and nutrition related cancers, as public health priorities. $\mathrm{He}$ would always seek sound reasoning as an underlying concept for the causes and prevention of illness. ${ }^{5}$

Then there was the creative impatience that would not allow him to await the outcome of tedious laboratory studies, but seek alternative routes to a goal. For instance, while he acknowledged the need for molecular biology studies, or for DNA adduct studies with reactive metabolites of tobacco carcinogens, he could not see that ultimately such research would bear fruit in disease prevention in the way, and at the rate, child health education could. The magnitude and the social impact of cancer and its relation to tobacco use and diet as major causes, and the low rate of success of many modes of intervention, convinced Ernst Wynder that child health education is the only way to avert the continuation of the tobacco cancer epidemic. Thus, he conceived the idea for and implemented the creation of the "Know your body program". It is fair to say that the children of this world have now lost a very good and caring friend.

Many call Ernst Wynder "the health conscience of the nation" because of his incessant prodding of governmental authorities and societal institutions to involve themselves in issues of chronic disease prevention and health promotion. He gave much thought not only to pathogenic agents but also to human conditions that foster the development of disease or of unhealthful behaviour. In terms of children's receptivity to health education messages, he turned his attention in recent years to research on brain development and how it is positively and negatively affected by the child's physical and emotional environment. Similarly, he became very interested in reviewing what is known about the nocebo effect versus positive attitudes in the prevention of illness and in the outcome of treatment. In this context, he also was very much concerned about the trends toward alternative (complementary) medicine concepts and he felt that much could be learned and gained from rigorous scientific examination of such concepts.

Ernst Wynder clearly saw that $80-95 \%$ of cancer and various other chronic diseases were in the end man made and, therefore, preventable. This is why he established the American Health Foundation in New York (Manhattan and Valhalla) as a free standing disease prevention centre 30 years ago. He strongly recommended that teaching prevention skills should be given greater weight at medical schools, and that physicians should be given incentives to practise preventive medicine. $\mathrm{He}$ was hopeful that the implementations of dietary changes to low fat, high fibre nutrition which proved effective in model assays in the laboratory, would be proven to save women with breast cancer from developing a second primary breast cancer, and that the results of chemoprevention assays in the research laboratory would soon translate into clinical applications for the benefit of people at high risk for cancer.

He established the international journal Preventive Medicine as a forum for the exchange of ideas and concepts of disease prevention and health promotion, and served as its editor in chief to his last day. His efforts and achievements have been recognised by his peers, by governments, and by medical schools here and abroad with numerous awards and honorary degrees. He will be missed by his wife Sandra Miller Wynder, his sister Lore Levinson, and his nephews, Robert and Martin Levinson, both physicians. He will also be dearly missed by all the children for whom he recreated the National Child Health Day, that had first been instituted by Calvin Coolidge in 1928. It was for them that he held high hopes for a healthier tomorrow.

New York, NY, USA

DIETRICH AND ILSE HOFFMANN

ilsel.hoffmann@worldnet.att.net

1 Wynder EL. Tobacco as a cause of lung cancer with special reference to the infrequency of lung cancer among non-smokers. Pennsylvania Medical fournal 1954;57:107383.

2 Wynder EL. The past, present, and future of the prevention of lung cancer. Cancer Epidemiol Biomarkers Prev 1998; 7:735-48.

3 Wynder EL. Tobacco as a cause of lung cancer: some reflections. Am 7 Epidemiol 1997;146:687-94.

4 Kluger R. Ashes to ashes. New York: Alfred Knopf, 1996.

5 Wynder EL. Listen to nature: the challenge of lifestyle medicine. Sozial Präv Med 1991;36:137-46. 